Young Feminist Activists in Present-Day China: A New Feminist Generation?

\title{
Qi Wang
}

\section{OpenEdition}

\section{Journals}

Electronic version

URL: http://journals.openedition.org/chinaperspectives/8165

ISSN: 1996-4617

\section{Publisher}

Centre d'étude français sur la Chine contemporaine

\section{Printed version}

Date of publication: 1 September 2018

Number of pages: $59-68$

ISSN: 2070-3449

\section{Electronic reference}

Qi Wang, « Young Feminist Activists in Present-Day China: A New Feminist Generation? », China

Perspectives [Online], 2018/3 | 2018, Online since 01 September 2019, connection on 28 October 2019. URL : http://journals.openedition.org/chinaperspectives/8165 


\title{
Young Feminist Activists in
}

\section{Present-Day China}

\author{
A New Feminist Generation?
}

\begin{abstract}
This article studies post-2000 Chinese feminist activism from a generational perspective. It operationalises three notions of generation-generation as an age cohort, generation as a historical cohort, and "political generation"-to shed light on the question of generation and generational change in post-socialist Chinese feminism. The study shows how the younger generation of women have come to the forefront of feminist protest in China and how the historical conditions they live in have shaped their feminist outlook. In parallel, it examines how a "political generation" emerges when feminists of different ages are drawn together by a shared political awakening and collaborate across age.
\end{abstract}

\section{KEYWORDS: post-socialist Chinese feminism, generation, feminist activism, China, age cohort, historical cohort, political generation.}

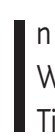
n March 2015, right before the annual celebration of International Women's Day, five young feminists known as the Feminist Five (Wei Tingting, Li Tingting, Wu Rongrong, Wang Man, and Zheng Churan) were arrested by the Chinese police for planning to spread messages against sexual harassment in public transportation. Shocking as it was, the news brought great international attention to this "increasingly vocal group of young activists" (Mohanty 2016: ix; Wang 2015; Jacobs 2015; Hu 2016). Subsequently, both the term "generation" and "wave" have made their way into the headlines of Anglophone media coverage (Chen 2015; Volodzko 2015). Similar terms such as "young activists" and "younger generation" are also regularly found in the emerging scholarship on the new feminist activism associated with these young women (Liu et al. 2015; Wesoky 2017). In Chinese social media, these young women are often referred to as the "new generation" (xin shengdai / xin yidai 新生代/新一代) or "Youth-Feminist-Action-Faction" (qingnian nüquan xingdongpai 青年女权行动派). (1) With these words, both academia and the media are joined in heralding the rise of a new feminist generation in China.

These young women "entered the central stage of feminist protests" by voicing "their anger at the growing sexism and gender inequality in China today" (Mohanty 2016: ix) through a series of performance art events targeting sexual harassment in public transportation, domestic violence, gender discrimination in education admissions, lack of female toilets in cities, and other forms of sexual abuse of women and school girls since 2010. Current studies of the new feminist activism have delineated these young women as action-oriented. They use provocative performance art on the streets to speak directly to the public and arouse public attention (Wei 2015; Jacobs 2016). They practice "media activism," leveraging "various platforms of communication" in the media and social media to spread their messages and "achieve their objectives" (Tan 2017: 175; Li and Li 2017). Moreover, they resort to individualised and "deinstitutionalised" tactics and loose networks instead of formal organisations (Wei 2015; Yue 2015), and finally, in contrast to the "non-confrontational and co-existence" approach of the earlier fem- inists who favour feminism as "female or feminine-ism" (nüxing zhuyi 女性 主义), these young activists prefer "women's rights or power-ism" (nüquan zhuyi女权主义) and are proud of being "feminist for women's rights/power" (nüquan zhuyizhe女权主义者). (2) They have hence distinguished themselves from feminists of the earlier reform period and mark a turning point in postsocialist Chinese feminism. Calling them a "new generation" is an expression for such change.

This study joins the current scholarly and media interest in the new generation of feminist activism with more focus on the concept of "generation." The aim is to flesh out the "generation" tag that we often use to describe the young feminist activists and to address the question of generation and generational change in post-socialist feminism in China on more theoretically-conscious ground. Three notions of generation are chosen for this purpose. The first is the notion of generation as an age cohort. It considers age as "one of the most basic social categories of human existence and a primary factor in all societies for assigning roles and granting prestige and power" (Braungart and Braungart 1986:205) and theorises "the nature and significance of biological age groupings for process of social change and continuity" (Pilcher 1994: 481). The second is the notion of generation as a historical cohort. This notion views generation as "a historical construct that transcends the biological chronology of life from birth to death" (Aboim and Vasconcelos 2012: 7) ${ }^{(3)}$ and draws attention to the role of historical

1. See "中国青年女权行动派与我” (Zhongguo Qingnian nüquan xingdongpai yu wo, Young Chinese feminist activists and me), Xinlang Blog, 14 June 2016, http://blog.sina.cn/dpool/blog/ s/blog_67c528700102wkg5.html (accessed on 28 March 2017);Voiceyaya “新时代的新生代女 权运动” (Xin shidai de xin shengdai nüquan yundong, New feminist movement of the new generation in the new epoch), Xinlang Blog, 8 March 2016, http://blog.sina.com.cn/s/ blog_5bf3c11f0102wbjj.html (accessed on 28 March 2017); Ye Haiyan 叶海燕, “青年女权行动 派的孩子们” (Qingnian nüquan xingdongpai de haizimen, Those youth-feminist-action-faction kids), http://p.t.qq.com/longweibo/index.php?id=455771028824365 (accessed on 27 September 2017).

2. For more information about the dual connotation of "feminism" in Chinese, see Ko and Wang (2006).

3. For a published version of the article see European Journal of Social Theory 17(2):165-83. 
events and conditions in shaping people's identity and political consciousness. The third is the concept of "political generation," which accentuates the "cultural and political environment in a community context" and explores how people of diverse ages and backgrounds are drawn together by "similar political awakening" (Reger 2014: 6).

Guided by these notions of generation, the article will focus on: 1) the role of age in the new feminism; 2) the influence of historical experiences on feminist coming-of-age and identity formation; 3) the process and location of feminist fermentation and mobilisation. The aim is to shed light on the dimension of generational differences but also cross-generational connection and continuity in post-socialist Chinese feminism. The theoretical ground of this study is based on generation literature in social science and feminist history that I have come across. The selection might be limited in scope, given the sheer size of the international scholarship on generation and feminist generations. Empirical data about the young feminist activists is mainly collected from various Internet sources in a "targeted" manner, whereby I type certain key words, such as "Chinese feminism" (Zhongguo nüquan 中国女权) and "youth-feminist-action-faction" (qingnian nüquan xingdong pai 青年女权行动派), retrieve different entries from mixed sources within the last two or three years, and retain only those facts and information that are relevant. (4) In addition, I interviewed three individuals and communicated with one person from China. The interviews took place in Denmark by using the hold-to-talk voice messaging function of the Chinese social media WeChat. They include $X$, a key figure amongst the young feminist activists in Beijing; $S$, a high-profile feminist scholar from Shanghai with profound knowledge of feminism and the new feminism in China; W, a sociologist who has interviewed some of the young feminist activists and published an article about them; and Li Sipan, a feminist journalist in Guangzhou. ${ }^{(5)}$

\section{The new feminist generation as an age cohort}

In sociology and social science in general, the notion of generation connotes a set of meanings, and age cohort is one of them. ${ }^{(6)}$ An age cohort is a group of people who have been born and grown up within the same or relatively the same period. Based on the recognition that "the distinct ages of life act as conditioning forces for human experiences" (Braungart and Braungart 1986: 206), Western generation theories postulate that "those born around the same period in time share a similarity in both life-cycle development and historical experiences" (ibid:: 205-6). Age groups thus have the potential to function as "agents of social change" (Kerzer 1983: 133) and bear great significance for the study of "human behavior and politics." The "entrance of successive age groups into society shapes the course of human development and sociopolitical change" (Braungart and Braungart 1986: 205-6).

Thus, to understand the young feminist activists as a new feminist generation, the first step is to locate their age cohort and deliberate the role of age in making them the way they are. In general, the young feminist activists have emerged from the population segment that was born in the 1980 s and 1990s. People in this age cohort are commonly referred to as the post-1980s, post-1990s generation, '80ers and '90ers, or the millennial generation (Zhao 2011; Rosen 2009; Sabet 2011; Yan 2013; Yi, Ribbens, and Morgan 2010). Typically, these young women are in their late twenties or early thirties. When the Feminist Five were arrested in 2015, for instance,
Wang Man was 33 years old; Wei Tingting was 26; both Zheng Churan and Li Tingting were 25, and Wu Rongrong had just turned 30. ${ }^{(7)}$ Xiao Meili, the women's rights activist who completed a 2,000 km walk from Beijing to Guangzhou in 2014 to raise public awareness of sexual abuse, was born in 1989, ${ }^{\left({ }^{8}\right)}$ whereas my informant $X$ was born in 1988 and will be 30 this year. ${ }^{(9)}$

People of this generation possess some characteristics that are different from those of their parents' generation. As they have advanced toward adulthood, Chinese society "has undergone an ethical shift from collectiveoriented values to individual-oriented values" (Yan 2010: 2). The influence of public forces on the family has weakened, and the individual has gained "greater control (...) over her or his life" (ibid.: 1). Studies of individualisation in China have shown how "the primacy of personal happiness and individual realisation" has become "the ultimate goal in life" for post-1980s and post1990s youth (ibid.: 2). On the negative side, they are often described as "selfish," "uncooperative," "anti-traditional," and "rebellious," but they have also been associated with positive attributes such as "strong self-confidence," "diverse interests," "strong need for self-improvement," and "better connection to the outside world" (Yi, Ribbens, and Morgan 2010: 605). These generational characteristics explain, at least in part, why women of the new generation would "reject the politics and methods of their predecessors" and choose new modes of action that they feel "are more effective" and illuminative to who they are (Hunt 2017: 108).

But age location also mirrors an age group's social placement. Being in their late twenties or early thirties, the young feminist activists are either university students, fresh graduates, or individuals with diverse educational and occupational backgrounds. They have not advanced high enough on the social ladder to obtain an established status, and therefore lack "social capital, social networks, and professional qualifications within the system" (Li and Li 2017: 58). What they have, conversely, is their individual initiative, strong sense of agency and social justice, and high degree of commitment and creativity. This explains why the new feminist activism arises from the outskirts of the state system and the state-sanctioned organisational channels and why it mostly accentuates individuals and volunteers. In the absence of governmental resources, news-making becomes the "major means of mobilization" for the young feminist activists, while street-based performance art and media/social media have proven to be two effective tools for them to make news (ibid.).

Since age cohort is an aggregative category, one may wonder how large this new feminist generation is. The question is easier to ask than to answer, given that the activist groups participating in the street actions in 2012 were not strictly organised and that there are basically "no statistics about

4. A Google search for "youth-feminist-action-faction" (qingnian nüquan xingdong pai 青年女权 行动派) gives 17,900 entries, "new generation feminists" (xin shengdai nüquan yundong 新生代 女权运动) gives 24,900 entries and "Chinese feminism" (Zhongguo nüquan 中国女权) gives 365,000 entries.

5. As agreed upon, all the interviewees will be referred to anonymously in the article.

6. The four categories of generation are: 1) generation as a principle of kinship descent; 2) generation as an age cohort; 3) generation as a life stage; and 4) generation as a historical period. For more about generation, see Kerzer (1983: 126)

7. "Meet the 5 Female Activists China Has Detained," The New York Times, 6 April 2015, https://cn.nytimes.com/china/20150406/c06womenprofiles/ (accessed on 25 September 2017).

8. See Shi Yuhan 施钰涵, “在新一代女性权益伸张群体的眼里,标签和光环并不重要” (Zai xin yidai nüxing quanyi shenzhang qunti de yanli, biaoqian he guanghuan bingbu zhongyao, In the eyes of the new generation groups who uphold women's rights, tags and fame are not important), Vice, 1 December 2015, http://www.vice.cn/read/gen-y-feminists-dont-care-abt-tags-and-fame (accessed on 28 September 2017).

9. Interview with $\mathrm{X}, 10$ October 2017 
the number of feminists or the number of feminist activists in China." (10) Most of the protest performances were "executed by a small number of actual participants," sometimes "even a single individual" (Wei 2015: 294). The "Occupy Men's Room" event in 2012, for example, was carried out by around 20 young women in Guangzhou and Wuhan respectively, 17 in Xi'an (with nine boys), (11) and about 10 in Beijing and Chengdu respectively. ${ }^{(12)}$ However, the numbers would be much larger if including those who were not at the scene of the protest but supported the campaign behind the scenes. As the People's Web (renmin wang 人民网) reports, female students from 12 of China's normal universities have sent letters to their university authorities appealing for more female toilets (Zhou 2012).

\section{The new feminist generation as a historical cohort}

The notion of generation as a historical cohort stems from sociologist Karl Mannheim, who saw generational location as "a key aspect of the existential determination of knowledge" yielding "certain definite modes of behaviour, feeling and thought" (Pilcher 1994: 483). A generation, in Mannheim's thinking, refers to "people within a delineated population who experience the same significant event within a given period" (ibid.). Therefore, "members of different political generation possess different perspectives" (Whittier 1997: 761). Ever since Mannheim, sociologists have "recognized the lifelong influence that historical events shared by cohorts can have on beliefs about the world and self" (Schnittker et al. 2003: 608). Likewise, Western feminism studies also underscore how "the contentious course of political debates about the meaning and substance of feminism" have had "different aggregate effects on identification for those whose political coming-of-age has occurred at different times" (ibid.).

The concept of "historical cohort" emphasises the historical experiences that members of a cohort share with one another and the impact of these experiences on the formation of their self-consciousness, identity, and worldview. At this point, we can identify three historical conditions that today's young feminists have lived in and examine how these conditions have influenced them. The first to mention is that they grew up during the later reform period under the market economy and market-defined social and cultural conditions. ${ }^{(13)}$ By the time they reached their earlier adulthood, China's economic reforms had deepened, gender discrimination had become widespread, and women's conditions in general had deteriorated. ${ }^{(14)}$ As Xiao Meili, one of the young feminist activists, states (Volodzko 2015):

In China today, women face widespread discrimination at work; many companies refuse to even hire women. Sexual harassment is commonplace. Domestic violence is pervasive.

During this period, traditional gender ideology and male chauvinism have also been on the rise (He 2001; Leung 2003; Zhang et al. 2014; Zurndorfer 2016). Rampant patriarchal views flood the mainstream media, with many coming from the mouths of well-known male professors/experts (Shimei Keyi 2014). A recent survey on "gender equality awareness" conducted by the China Women's Journal amongst the students of 13 Chinese universities shows that $65.1 \%$ of the surveyed female students identify themselves with the idea of gender equality, whereas the same attitude was found amongst only $35.0 \%$ of the male students. It also shows that $40.48 \%$ of the male respondents would like to see women as full-time housewives, but only
$31.55 \%$ of them agree that the male should pay the bill for dinner during a date. Commenting on the results of this survey, the message board administrator of Baidu Post Bar concludes that the better educated men are, and the higher their academic qualifications, the more likely they will lean on traditional views of women and male chauvinist views. ${ }^{(15)}$

At a personal level, many young activists have experienced gender discrimination in one way or another at some point of their lives. In Xiao Meili's case, it is in the domain of love and intimate relations that she encountered unfairness. A young university student majoring in design, she loves painting, art, literature, travel, and pets. Like many young girls her age, she dreams about romance and a Prince Charming in her life. She carefully preserves her virginity, waiting for the moment of her "first time" to come. She did date a male classmate once, but the relationship did not thrive. Later, a senior fellow student showed an interest in her. The boy grew suspicious when he found out that Xiao had dated someone before and the couple had spent a night together. Though Xiao explained to him that nothing happened during that night, the new boyfriend didn't believe her: "You two were in the same room for a whole night, and you want me to believe that you were there just watching TV?" At that moment, a strong sense of unfairness swept over Xiao. She was infuriated by men's virgin complex, feeling treated like a thing worth possessing only if her virginity is intact. ${ }^{(16)}$

$X$, another young feminist, comes from a small town in central China. During her childhood, she repeatedly witnessed how her father beat her mother and bullied her with a rude and male chauvinist attitude. As a five-year old child, she had already developed a strong sense of justice and would fight back to protect her mother by slapping her father's head with a fly-swatter (Interview 3). Wu Rongrong, one of the Feminist Five, grew up in "an extremely patriarchal environment where girls were considered worthless." Too many times, she witnessed "promising young girls" from her village being "forced to abandon their studies and go to work to support their

10. Quoted from "Feminism in China," http://www.feminisminchina.com/\#daughtersofchina (accessed on 14 November 2017).

11. See “广州女大学生'占领男则'争平等" (Guangzhou nüdaxuesheng "zhanling nance" zheng pingdeng, Female university students "occupy men's room" to fight for equality). BBC (Chinese), 23 February 2012, http://www.bbc.com/zhongwen/simp/chinese_news/2012/02/120223_china_ women_toilet.shtml (accessed on 20 September 2017); “武汉女大学生关爱女性 '占领男则' 吓跑入则男" (Wuhan nüdaxuesheng guan'ai nüxing "zhanling nance," xiapao rucenan, Wuhan female university students care for women, "occupy men's room" and scare away male toilet users), Changjiang Ribao, 10 March 2012, http://news.fdc.com.cn/mrrd/419274.shtml (accessed on 20 September 2017); “女大学生'占领男则'三分钟, 呼吁改善刏位比例” (Nüdaxuesheng "zhanling" nance sanfenzhong, huyu gaishan cewei bili, Female university students "occupy" men's room for three minutes to appeal for improving the male/female toilet ratio), Sanqin doushibao/yangguangbao, 19 March 2012, http://xian.q9.com/a/20120319/000020_4.htm (accessed on 15 September 2017).

12. See "占领男则所-行为艺术呼吁侧位平等" (Zhanling nancesuo-xingweiyishu huyu ceweipingdeng, Occupy men's room - performance art appealing for equality in toilet seats), Nüquan zhisheng, 27 February 2012, https://www.douban.com/doulist/30595097/ (accessed on 22 September 2017).

13. See Zhao (2011) and Sabet (2011).

14. In an article titled "A Social Environment Analysis of the Change of Women's Status in China," Chinese scholar He Qinglian outlines four pressures on women that have a great impact on the value orientation of Chinese women today. These are high unemployment rate/difficulties finding a job, sexual harassment in the labour market, marriage and family embrittlement, and marriage pragmatism and sexual commercialisation. For more about women's conditions and gender inequality in China, see Wang et al. (2016) and http://www.feminisminchina.com/overview/.

15. Jingjing lingkui 菁菁菱葵, “从中国妇女报对高校女、男学生性别平等意识调查看如今中国 女权” (Cong zhongguo funübao dui gaoxiao nü nan xuesheng xingbie pingdeng yishi diaocha kan rujin zhongguo nüquan, Viewing gender equality in present China from the survey of gender equality awareness amongst university students), Nüquan ba, 30 October 2016, https://tieba.baidu.com/p/4843037739 (accessed on 27 July 2017).

16. See “青年女权行动派剪影一: ‘小跟班'要“美丽”' (Qingnian nüquan xingdongpai jianying yi: "xiaogenban" yao "meili," Profile of the Youth-Feminist-Action-Faction: "small follower" wants to be "beautiful"), Nüshengbao, 15 January 2013, https://site.douban.com/179615/widget/notes/ 10246258/note/258144940/ (accessed on 10 May 2017). 
brothers' education." Wu's own pursuit of education was also "hampered not only by severe economic hardship but also by well-meaning people who tried to dissuade" her from continuing her education. In her young adult life, like all her female friends, Wu "encountered harassment when looking for full-time work." She was once lured to a suburb of Beijing by a man who posed as an employer promising her a job. In the end, she managed to get herself out, but the experience scared her and reminded her how vulnerable a young woman can be (Wu 2016).

The second historical condition to mention is the one-child policy and its wide social ramifications (Fong 2002, 2006; Tsui and Rich 2002; Arnold and Liu 1986; Wang 2005; Hannum and Zhang 2009). The young feminist activists represented by the Feminist Five belong to the one-child generation, and most of them, but not all, were brought up as the only child in their family (Sabet 2011; Wu 2015). Their parents have high expectations for them and have invested colossal economic resources to secure them a bright future. In her interview with eight young urban feminist activists, Wu notes that five of them "graduated from top national universities and six of them had never experienced any discriminative treatment or hindrances from their parents" (Wu 2015: 37). Thus, one unintended consequence of the one-child policy has been the improvement of education for urban girls and the emergence of resource-strong "little empresses" besides "little emperors" (Wang 2017).

Highly valued by their parents, these young women have grown up with a high self-expectation and a firm confidence about their roles in society. While rural girls such as Wu Rongrong must fight hard to get an education, they all treasure their education and hope education will bring them a prosperous future. Only when they entered society after graduation did they begin to realise how their gender identity could be an obstacle to them. This "shared negative experience of being discriminated against as a woman" (Wu 2015: 37) forms a sharp contrast to the good education they have obtained and the high self-confidence and self-expectations these women have. This sharp contrast, in Professor Wang Zheng's view, explains why these young women were drawn to feminism and were animated to act for change (Wang 2017). As well-educated and competent individuals, they do not tolerate gender discrimination and are highly motivated to fight back.

The third historical condition to mention is these young women's detachment from China's socialist past and the legacy of state feminism. During the socialist period, the Chinese state launched waves of campaigns to "liberate" women and promote women's socioeconomic and political participation. This proactive and woman-friendly role of the state has, however, diminished since the economic reforms began and became unrecognisable for women of the new generation. On the contrary, they have discovered many loopholes and oversights in government policies and labour market praxis that either connive with or harbour discrimination against women and other socially disadvantaged groups. Moreover, the Chinese government has since the new millennium turned to revitalising Confucian family values and promoting traditional gender norms (Fincher 2016). In concert with the state, the All-China Women's Federation (WF), for example, instigated a national campaign to urge single professional women over 27 to get married. Those who remained unmarried were mobbed as undesirable "leftovers" (Fincher 2014, 2016). The conservative turn of the state (and the state institution of women, WF) has evoked a strong disappointment among women of the new generation and pushed them to resist (Fincher 2016).
These historical conditions are fundamentally different from those under which feminists of the older generation have lived. They therefore served as formative moments for women of the new generation and have prepared the soil for a new and different feminist political outlook to grow. Taking these conditions into consideration helps illuminate why these young women have little tolerance for gender discrimination and social injustice; why they react spontaneously to gender discriminative actions and language; why they have replaced the soft version of feminism (nüxing zhuyi女性主义) with the hard one (nüquan zhuyi 女权主义); and why they do not see the state as a friend and have developed a more "oppositional" and "confrontational" profile.

\section{The notion of "political generation": Feminist mobilisation and collaboration across age}

A political generation is "constructed socially rather than temporally." It "forms, not after an arbitrary number of years, but in response to significant changes in the environment and corresponding changes in individuals' 'transformative experiences'" (Whittier 1997: 762; Schuman and Scott 1988). Originally coined by sociologist Karl Mannheim, the notion of "political generation" has been further developed lately. In a study of women's movements from 1969 to 1992 in Columbus, Ohio, Whittier defines political generation "as being comprised of individuals (of varying ages) who join a social movement during a given wave of protest" (Whittier 1997: 762). In a recent study of feminism in the twenty-first century United States (Cullen and Fisher 2014), Jo Reger puts forward the term "similar political awakening" and postulates that a political generation "is a group of people who share a similar political awakening brought about by societal changes" (Reger 2014: 6). This definition is apt for "understanding patterns of continuity and change across generations of feminist mobilisation," as it emphasises "similar political awakening" rather than age (Cullen and Fisher 2014: 285). Political generations are thus "a product of experience, ideology and identities forged by the time activists are living" and hence are "not monolithic" (ibid:: 285-286). The idea of political generation "resists the sequential notion that younger generations replace the older ones" and argues that "feminist generations overlap, creating both cooperation and dissention in the movement" (ibid.: 286).

To follow this line of thinking, I examine the process of becoming feminists and feminist fermentation to discover how feminists of the new generation get inspiration from the older generation while making a difference. In the first place, the first step towards feminism varies from individual to individual; some of them simply "bumped into" feminism by chance. Zheng Churan, for instance, accidentally found a book on anti-domestic violence in China in the university library. The book analyses domestic violence in China from a gender perspective and awoke Zheng's interest in gender and feminism (Lee 2016). Li Tingting once participated in a sexual education session offered by an NGO while she was studying at the university. The session introduced the concept of gender to her for the first time and she was drawn to it immediately. ${ }^{(17)}$ Wei Tingting read news about the feminist theatre play The Vagina Monologues from a newspaper she found at a local optician's shop. Curious, she searched for more information and ultimately organised

17. Liang Yan 梁彦, “专访：中国女权行动者李麦子” (Zhuanfang: Zhongguo nüquan xingdongzhe Li Maizi, Special interview: Chinese feminist activist Li Maizi), Radio Canada International, 17 June 2016, http://www.rcinet.ca/zh/2016/06/17/56750/?utm_source=dlvr.it\&utm_medium=facebook (accessed on 28 September 2017). 
a performance of the play at her own university (Zhang, Xiao, and Jiang 2014). Xiao Meili came to know an NGO in Beijing through a movie advertisement. She then began to attend lectures there regularly and discovered a "secret" - gender perspective-and met people with whom she felt a connection. ${ }^{(18)}$ Following these anecdotes, I tracked down two ongoing processes and a few feminist environments that have prepared the ground for the new feminism and have sown the seeds of feminist activism amongst women of the new generation.

\section{The two ongoing processes}

One is the availability of various gender studies courses at universities, including feminist and gender studies literature and textbooks, and gender training programs under the auspices of NGOs. The Shanghai-based feminist scholar I interviewed confirms that some young feminist activists attended gender studies classes taught by her and her colleagues, and some young women attending the classes did become feminist activists. ${ }^{(19)}$ A prominent example of this ongoing gender training process can be found in a diaspora organisation called Chinese Society of Women's Studies (CSWS) (Haiwai zhonghua funüxue xuehui 海外中华妇女学学会) with Professor Wang Zheng of the University of Michigan as the frontrunner. In an interview with the web editor of ChinaChange.org, Wang Zheng narrates how in 2002 she began to collaborate

(...) with the China Women's College and the Chinese University of Hong Kong for a three-year training program [in gender and women's studies]. China Women's College has become the first university in China with a bachelor's degree in women's studies. After I took a teaching position at the University of Michigan, I still went back to China every year [to continue the training program]. Furthermore, I set up a base at Fudan University, the University of Michigan-Fudan University Institute for Gender Studies, and taught during summer vacations. Several feminist activists attended my class last year (not the ones who were arrested), so they are directly our students. I am also well acquainted with one of the Five; she had been to my class as well. (20)

In a blog article written by a feminist journalist based in Guangzhou, these training classes are given the nickname "Whampoa Military Academy," referring to the Whampoa Military Academy in the Republican period where many KMT and CCP members were trained to became top political/military leaders of both parties. (21)

The other ongoing process is the spread of The Vagina Monologues, an episodic feminist play written by American feminist playwright Eve Ensler. ${ }^{(22}$ Brought to China by feminist professor Ai Xiaoming of Sun Yat-sen University in 2003, the play has been adapted into different versions and performed in many Chinese cities by either university student groups or NGOs. ${ }^{(23)}$ The universities on the list include Fudan University, Peking University, Central China Normal University, Wuhan University, Xiamen University, and Capital Normal University. (24) Many of the young women who later became the backbone of the new feminist activism were educated in these universities. Professor Rong Weiyi of the Chinese People's Security University names the spread of The Vagina Monologues as "a wind vane" for Chinese feminism, especially in terms of combating gender-based violence. ${ }^{(25)}$ In Ai Xiaoming's view, the Chinese versions of The Vagina Monologues are not simply a copy or transplantation of the original. Rather, they constitute a new theatrical creation that is both based on and speaks to Chinese women's experiences. The Chinese versions of The Vagina Monologues break cultural taboos, candidly disclose widespread praxis of gender discrimination and inequality in Chinese society, and spotlight media bias in issues of gender, sex, and sexuality. And it is through the stage narrative and performance that the voice of women and other disadvantaged groups have come to be expressed and heard. (26)

The feminist enlightening effect of The Vagina Monologues cannot be underestimated. At an internal meeting of a student organisation called Zhihe Society at Fudan University in 2017, earlier presidents and board members gathered to share their personal experiences in acting in The Vagina Monologues. Lin Mu, who worked with backstage lightning for The Vagina Monologues performance in 2006, recalled how he felt when watching the show for the first time. "It was really, really shocking." (27) Luo Shengmen, one of the four main actresses in the 2007 Vagina Monologues show at Fudan, describes:

[the acting process] helped me to form my self-identity. I became certain about my being a lesbian and accepted myself the way I am.

Xiaomeng, the president of the organisation between 2008-2009, has been part of the performances for years. For her, the best part about acting in The Vagina Monologues is that (ibid.):

(...) after sessions and sessions of discussion and critical reflection, we finally reach the point where we dare to accept our own experiences and share new points of view with one another. I have obtained various new perspectives.

Deannie, once president of the organisation, screenwriter and actress in the 2009 Vagina Monologues, and director of the 2012 Vagina Monologues, recalls how she felt when she read the script for the first time:

18. See Lei Ma, “阴道独白'在中国的十年" ("Yindao Dubai" zai Zhongguo de shinian, The Vagina Monologues' ten years in China), Helan zaixian, 17 July 2013, https://helanonline.cn/archive/article/5131 (accessed on 18 August 2017).

19. Interview with S, 27 September 2017.

20. “王政教授访谈: 女权五姐妹的被捕与中国女权运动政治化, 以及女权运动的国际图景 " (Wang Zheng jiaoshou fangtan: nüquan wujiemei de beibu yu Zhongguo nûquan yundong zhengzhihua, yiji nüquan yundong de guoji tujing, Interview with ProfessorWang Zheng: The arrest of feminist five sisters and politicisation of Chinese feminist movement, and the international view of feminist movement), ChinaChange.org, 10 April 2015, https://commondatastorage .googleapis.com/letscorp_archive/archives/87704 (accessed on 19 July 2017).

21. Li Sipan 李思磐, “中国版女权主义启蒙到自觉 (Zhongguoban nüquanzhuyi qimeng dao zijue, The Chinese version of feminism: From enlightenment to consciousness), Caijing, 10 February 2015, http://chuansong.me/n/1146975 (accessed on 27 September 2017).

22. Joyce Man, "10 Years of The Vagina Monologues in Mainland China," Oxfam Hong Kong, 27 December 2013, http://blog.oxfam.org.hk/wordpress/?p=1860 (accessed on 24 September 2017).

23. Lei Ma, “阴道独白'在中国的十年” (Yindao Dubai zai Zhongguo de shinian, The Vagina Monologues ten years in China), Helan zaixian, 17 July 2013, https://helanonline.cn/archive/article/5131 (accessed on 18 August 2017).

24. Ibid.

25. Weiyi Rong 荣维毅, “阴道独白' 中国大陆演出十年记” (“Yindao Dubai" Zhongguo dalu yanchu shinian ji, The Vagina Monologues. 10 years of performance in Mainland China), Sinablog, 21 May 2013, http://blog.sina.com.cn/s/blog_9ed297970101axzc.html (accessed on 10 September 2017).

26. See “全球女权主义口述史访谈：艾晓明" (Quanqiu nüquanzhuyi koushushi fangtan: Ai Xiaoming, Global Feminist Oral History Interview:Ai Xiaoming), https://globalfeminisms.umich.edu/ sites/default/files//aixiaoming_m.pdf (accessed on 15 December 2017).

27. “知和无姓之人: 一个高校社会性别议题社团的十一年” (Zhihe wuxing zhiren: yige gaoxiao shehuixingbie yitishetuan de shiyinian, Nameless persons of Zhihe: Eleven years of a gender-issuefocused student association), 31 March 2016, http://www.ngocn.net/news/2016-03-3017f5532ef2cb0a83.html (accessed on 24 October 2017). 
It struck me like thunder! I had a lot of questions and confusion in my life. Suddenly, I saw the light and my self-oppression was gone.

Another previous president of the organisation and participant in the 2012 Vagina Monologues tells:

[the acting experience] made feminism sprout in me. I did not have a clear self-identity before. Most of the time I viewed homosexuality through my 'straight' lens, lacking a nuanced understanding of gender, and my mind was seriously stereotyped.

Damao became a member of the organisation in 2012 and has performed The Vagina Monologues for four years. For her, acting in the show made her mature, enabling her to speak up and openly express her feminist point of views (ibid.).

In Beijing, a volunteer activist group consisting of 10 permanent members called Bcome "was (...) behind the performance of The Vagina Monologues by BFSU students." (28) Being set up in September 2012, the group put on the first show in January 2013 and has since given 10 performances in Beijing and Tianjin and received fervent audience responses. ${ }^{(29)}$ The name of the group itself is highly symbolic. On the one hand, Bcome is a homophone for "become," implying to become yourself and who you want to be. On the other hand, B is also a homophone for the vulgar Chinese slang for vagina ( $b i$ 屄), so Bcome also announces the arrival of the vagina and women's orgasm.

[The show organisers] translated the play from the English script, took parts from past Mandarin versions, and created original scenes through a series of workshops they ran last year. At each workshop, they voted on the topic they wanted to stage, noted down their own experiences, and gave key words to the scriptwriters. ${ }^{(30)}$

As Ai Ke, one of the organisers, explains, "We wanted to localise the play as much as possible, so we added issues like virginity obsession and anxiety" (ibid.). In an interview with Lei Ma, Ai Ke explicitly states that:

We are an action-oriented group. Acting in The Vagina Monologues is a form of social movement. We hope to change society through activities like this.

\section{Furthermore, Ai Ke adds (ibid.):}

The play is new, fresh, and attention-grabbing. It's not just a play, it's a tool for spreading feminism and a means of public education.

$X$, a central figure amongst the young feminist activists, confirms in my interview that some of her friends do become gender sensitive and feminist-minded through performing The Vagina Monologues. ${ }^{(31)}$

\section{Geographically located feminist environments}

Apart from these two ongoing processes, a few geographically located feminist environments were found to have functioned as an incubator of feminist fermentation and cradled the young feminist activists for years. One is the Beijing-based Media Monitor for Women Network, "the first action-oriented group focused on media and gender in mainland China." (32) Since it was established in 1996, the network has carried out a series of activities to deal with a variety of issues, including domestic violence. ${ }^{(33)}$ Around 2009 and 2010, the network entered social media by launching its Sina microblogging account, Genderinchina (nüquan zhisheng 女权之声). Featuring "feminist viewpoints, civic vision, and action orientation," it soon became the most active feminist blog account that both mobilises and supports online feminist voices. In July 2011, a civil activity centre called "Yiyuan Commune" (Yiyuan gongshe 一元公社) was set up under the auspices of the Media Monitor Network. The Commune organises lectures, seminars, training, and reading sessions. In doing so, it has attracted a group of young potential feminists and become a source of inspiration and training ground for them. Many of the performance art activities that unfolded in 2012 were either directly initiated or supported by the Network. The organisation maintains close ties with the young feminists and provides them with communication, training, and moral support. In the view of feminist blogger Zhang Hongping, it is through the activities under the auspices of the "Yiyuan Commune" that many young female students have found the entrance to feminism and became actively involved in feminist activism. ${ }^{(34)}$ For $X$, the young feminist I interviewed, that was how she embarked on the journey to feminism. (35)

Behind Genderinchina there is an extraordinary and charismatic individual named Lü Pin. Born in 1972, Lü graduated from Shandong University in 1994 with a master's degree in Chinese. She then joined the national newspaper for women China Women's Journal (Zhongguo funübao 中国妇女报) as a journalist. She participated in the UN's Fourth World Women's Conference in Beijing in 1995, the event that triggered a strong wave of NGO organising in China throughout the 1990s. In 2004, Lü resigned from her job at the China Women's Journal to become a freelancer. She founded the electronic newspaper Women's Voice in 2009, which in 2011 was changed into Genderinchina on the Xinlang microblog. Within a few years, she turned Genderinchina into the most influential online platform for feminist articulation in China. From concrete ideas to general moral support, Lü firmly stands behind young feminist activists in Beijing and played a vital role in waves of feminist protest through performance art in and around 2012. Because of this, the Chinese government regarded her as the "invisible hand" behind the young feminist "troublemakers," and she had to flee China after the arrest of the

28. "Feminism in China," http://www.feminisminchina.com/\#daughtersofchina (accessed on 14 November 2017). See also https://helanonline.cn/archive/article/5131) (accessed on 18 August 2017).

29. Yu Chen 陈瑜, “阴道之道' 创作成员: 这剧目的就是制造不安” (“Yindao zhi dao" chuangzuo chengyuan: zhe ju mudi jiushi zhizao bu'an, Screenwriter of The Way of the Vagina: The purpose of the play is to cause unease), Fenghuangzixun, 17 December 2013, http://news.ifeng.com/shendu/renwu/detail_2013_12/17/32205989_0.shtml (accessed on 22 September 2017)

30. "Feminism in China" http://www.feminisminchina.com/\#daughtersofchina (accessed on 14 November 2017).

31. Interview with $X, 21$ October 2017

32. Yanhong Zhu, "Media Monitor for Women Network," Zhongguo funüwang, 31 July 2012, http://www.womenofchina.cn/womenofchina/html//source/14/3442-1.htm (accessed on 12 October 2017).

33. For the role of the network in fighting against domestic violence, see Milwertz and Bu (2007) and Zhang (2009).

34. Hongping Zhang 张红萍, “你所不知道的中国女权主义者” (Ni suo buzhidao de Zhongguo nüquanzhuyizhe, The Chinese feminists you might not know), Sina Blog, 21 October 2015, http://blog.sina.com.cn/s/blog_510e6bb0102vwqf.html (accessed on 28 March 2017).

35. Interview with $X, 10$ October 2017. 
Feminist Five in 2015. (36) In the view of feminist blogger Zhang Hongping, the turn to action in feminism, manifested through street performances, spells a fundamental change in post-socialist Chinese feminism. Such change would not have been possible without hard-core feminists such as Lü Pin and her years of tenacious engagement in gender and feminist issues. ${ }^{(37)}$

Another feminist environment that has nurtured the new feminist activism is found in Guangzhou, with the Sex/Gender Education Forum at Sun Yat-Sen University headed by Professor Ai Xiaoming and the Women Awakening Network serving as twin platforms. Born in 1953, Ai came to teach Chinese literature at Sun Yat-Sen University in 1994 and soon distinguished herself as a "filmmaker, literature professor, feminist and rights activist" (Zeng 2017: 184). In the words of Milwertz, Ai "is an avid supporter of struggles to claim the rights of the oppressed, discriminated and marginalized." She is also "an outspoken critic of injustice," using "documentary films as a central medium in her work" (Milwertz 2010: 31). In 2010, Ai was awarded France's Simone de Beauvoir Prize for her steadfast activism and remarkable commitment to women's rights. ${ }^{(38)}$ For years, Ai Xiaoming has organised lectures on sex and sexuality, trained her students to engage in feminist literature critique, and involved them in social activities. (39)

In 2003, Ai introduced the American stage play The Vagina Monologues to China and organised the first performance of this play in Chinese. ${ }^{(40)}$ The theatre performance proved to be an eye-opening experience for the student actors/actresses. In the same year, Ai Xiaoming vigorously involved herself and her students in two cases: one was the Sun Zhigang case, in which a young university student was detained by the police for not carrying identification papers and eventually died in police custody; and the other was the Huang Jing case, where a young woman died in bed with her boyfriend, probably due to rape. While sending protest letters to the authorities, and appealing for thorough investigation and fair trial, Ai Xiaoming also posted critical comments on Weblog and encouraged her students to make their own investigations of the cases. ${ }^{(41)}$ Through these and many other endeavours, Ai developed a feminist pedagogy and ushered many students onto the path of feminist activism. One of her Masters and Ph.D. students, Ke, became a feminist under the influence of Ai Xiaoming. In her subsequent career as a university professor, Ke has passed her passion for feminism on to her students as Ai Xiaoming did in her time. In an article in Nanfeng Chuang 南风窗 in 2013, Ke was described as a mentor and cardinal supporter of young feminists such as Zheng Churan and her peers. ${ }^{(42)}$

The feminist media network Women Awakening Network, established in 2004, was joined by a dozen journalists in Guangdong and is run by a younger but dynamic feminist journalist Li Sipan. ${ }^{(43)}$ Over the years, the network has functioned as a feminist hotbed in Guangzhou and has carried out various forms of attention-grabbing activities to advocate gender equality and women's rights. In facing the marginalisation of women's rights issues and the stigmatisation of female images in the conventional media, the network propagates gender sensitivity and critical journalism by launching media report workshops, public lectures, and media salons. ${ }^{(44)}$ The network has also been a major feminist watchdog in the social media with its outspoken feminist voices. As a formidable blog writer and debater, Li Sipan has kicked off several rounds of hot public debate on issues related to, for instance, sexual harassment legislation and gender discrimination in higher education enrolment. ${ }^{(45)} \mathrm{A}$ recent spectacular action of the network was the "massive online discussion on the meaning of International Women's Day" in March 2016. Li Sipan's blog post, calling for a feminist resistance of the "capitalist consumerist co-optation" of the International Women's Day celebration in China, set in motion a massive public debate about feminism/feminist resistance and received more than 100 million visits (Wang 2017: 177).

The two ongoing processes and the feminist environments in Beijing and Guangzhou are a testimony to the key role that feminists of the earlier generation have played in feminist socialisation and mobilisation among women of the younger generation. They developed various women's and gender study courses/training programmes and introduced the American feminist theatre play The Vagina Monologues into China. This "spiritual heritage" provided "nutrients" for the younger generation and ignited the spark of feminism in them. Within the feminist environments in Beijing and Guangzhou, feminism was passed on from the older generation to the younger generation. While functioning as a training ground for young women to become critically-minded, socially engaged citizens and animated feminist, these environments also provided a common ground for feminists of varied ages to engage in feminist struggles across age and generational boundaries.

The connection and collaboration between the younger and older generation of feminists in brewing the new feminism warrants a generational perspective that is not strictly locked in age. In a sense, the feminist environments in Beijing and Guangzhou are two lively examples of political generation where feminists of different ages have come to work side by side. What binds them together is not biological age but rather a shared political awakening and feminist convictions. Thus, while recognising the role of young women in waging the new waves of feminist protest in China, we must bear in mind the notion of political generation and develop a perspective that can both "explain feminist movements in terms of differently aged (...)" and "take account of cross-generational feminist activism" (Cullen and Fisher 2014: 290).

\section{Concluding remarks}

This article studies the new feminist activism in post-2000 China from a generational perspective. It operationalises three notions of generation and explores how these concepts help us to shed light on the question of generation and generational change in post-socialist Chinese feminism. The first

36. Siling Luo 罗四鸰, “与'直男癌'对抗：中国女权在纽约” (Yu "zhinan ai" duikang: Zhongguo nüquan zai niuyue, Confronting the "straight men cancer": Chinese feminism in New York), Boxun, 13 February 2017, https://www.peacehall.com/news/gb/china/2017/02/201702131922.shtml\#. WcoV1bpuKM8 (accessed on 6 October 2017).

37. See “全球女权主义口述史访谈 : 艾晓明” (Quanqiu nüquanzhuyi koushushi fangtan: Ai Xiaoming, Global feminist oral history interview: Ai Xiaoming), https://globalfeminisms.umich.edu/ sites/default/files//aixiaoming_m.pdf (accessed on 15 December 2017).

38. See https://chinadigitaltimes.net/2017/02/person-week-ai-xiaoming/ (accessed on 26 January 2018).

39. See "Clobal feminist oral history interview: Ai Xiaoming," art. cit.

40. https://helanonline.cn/archive/article/5131) (accessed on 18 August 2017).

41. See广州新媒体女性网络" (Guangzhou xinmeiti nüxing wangluo, Guangzhou new media women's network), http://www.chinadevelopmentbrief.org.cn/org2141/ (accessed on 9 August 2018); Qinghui Zhen 甄静慧, “女权主义三重奏” (Nüquan zhuyizhe sanchongzou, Feminist trio), Nanfeng Chuang, http://www.qikan.com/article/D4EB3756-23F9-492F-8D12-3C8ED47D3DEE (accessed on 4 October 2017).

42. Qinghui Zhen, "Feminist trio," art. cit.

43. Ibid. See also my personal communication with Li Sipan via WeChat, 30 May and 14 August 2018.

44. See "Cuangzhou new media women's network," art. cit.

45. See Qinghui Zhen, "Feminist trio," art. cit. 
notion of generation as an age cohort highlights the relevance of biological age in identity formation/role assignment and the role of age groups in social change. As the study shows, the young women involved in the new feminist activism are in their late twenties or early thirties and belong to the post-1980s and post-1990s generation. This age "location" renders them a set of generational characteristics and a social placement that is different from feminists of the older generation, which in turn illuminates why women of the new generation "reject the politics and methods of their predecessors" and develop their own modes of action (Hunt 2017: 108).

The second notion of generation as a historical cohort sees generation as a historical construct and emphasises the impact of historical experiences on the formation of identity and political outlook of the cohort members. Feminist activism, in light of this view, should be "driven by more than just age" (Cullen and Fisher 2014: 284). At this point, this study identifies three historical conditions that young women of the new generation share: 1) their coming-of-age under the full-fledged market economy with deepened gender inequality and discrimination; 2) belonging to the one-child generation with better education and greater parental affection, material comfort, and self-expectations; 3) the historical "distance" between them and China's socialist/state feminism past. These conditions have served as formative moments for women of the younger generation and have fostered a new and different feminist political outlook among them. They have little tolerance for gender inequality; they react spontaneously to gender discrimination; they prefer the hard version of feminism (nüquan zhuyi 女权主义) to the soft one (nüxing zhuyi 女性主义); they do not see the state as a friend and have developed a more "oppositional" and "confrontational" profile.

\section{References}

ABOIM, Sofia, and Pedro VASCONCELOS. 2012. "From Political to Social Generations: A Critical Reappraisal of Mannheim's Classical Approach." Institute of Social Sciences, University of Lisbon http://repositorio.ul.pt/bitstream/10451/7742/1/ICS_SAboim_FromPolitical_Al.pdf (accessed on 20 April 2016).

ARNOLD, Fred, and Zhaoxiang LIU. 1986. "Sex Preference, Fertility, and Family Planning in China." Population and Development Review 12(2): 221-46.

BRAUNGART, Richard G., and Margaret M. BRAUNGART. 1986. "Life Course and Generational Politics." Annual Review of Sociology 12: 205-31.

CHEN, Yaya. 2015. "The New Generation of Chinese Feminists." E-International Relations 9 August. http://www.e-ir.info/2015/08/09/the-newgeneration-of-chinese-feminists/ (accessed on 5 April 2016).

CULLEN, Pauline, and Clara FISHER. 2014. "Conceptualising Generational Dynamics in Feminist Movements: Political Generations, Waves and Affective Economies." Sociology Compass 8(3): 282-93.

DUNCAN, Lauren E. 2010. "Women's Relationship to Feminism: Effects of Generation and Feminist Self-labelling." Psychology of Women Quarterly 34: 498-507.

ELDER, Jr. Glen H. 1992. "Models of the Life Course." Reviewed Works: The American Occupational Structure by Peter Blau and Otis Dudley Duncan. Contemporary Sociology 2(5): 632-35.

FINCHER, Leta H. 2014. Leftover Women: The Resurgence of Gender Inequality in China. London: Zed Books.

FINCHER, Leta H. 2016. China's Feminist Five. Dissent 63(4): 84-90.

FONG, Vanessa L. 2006. Only Hope: Coming of Age Under China's Onechild Policy. Stanford: Stanford University Press.
The third notion of generation as a "political generation" emphasises the role of "similar political awakening" in binding feminists together. While the notion of "age cohort" and "historical cohort" is apt for grasping generational differences, the notion of "political generation" fits better to shed light on feminist collaboration across age. In tracing the footsteps that women of the new generation have taken to become feminist activists, the study has identified two ongoing processes and a few feminist environments where feminist fermentation and mobilisation have taken place. Through these processes and within these feminist communities, feminists of different ages have thrown themselves together and worked side by side with one another to raise feminist voices and wage feminist protests. What binds them together is not biological age but rather a shared political awakening and feminist beliefs. From this perspective, the new feminism in post-2000 China constitutes vivid testimony to "political generation" across age boundaries. Thinking of feminism in terms of "political generation" allows us to move away from age-determinism, to appreciate feminist collaboration across age, and to uncover cross-generational connection and continuity amidst generational change.

\section{Qi Wang is Associate Professor in the Department of Design and Communication of the University of Southern Denmark. University of Southern Denmark, Alsion 2, 6400 Soenderborg, Denmark (qi.wang@sdu.dk).}

Manuscript received on 20 February 2018.

Accepted on 22 August 2018.

FONG, Vanessa L. 2002. "China's One-Child Policy and the Empowerment of Urban Daughters." American Anthropologist 104(4): 1098-109.

HANNUM, Emily, Peggy KONG, and Yuping ZHANG. 2009. "Family Sources of Educational Gender Inequality in Rural China: A Critical Assessment." International Journal of Educational Development 29: 474-86.

HE Qinglian 何清涟. 2001. “当前中国女性地位变化的社会环境分析” (Dangqian zhongguo nüxing diwei bianhua de shehui huanjing fenxi, A Social environment analysis of the change of women's status in China). Modern China Studies 2.

HU, Alice C. 2016. "Half the Sky, But Not Yet Equal - China's Feminist Movement.". HIR Harvard International Review 22 August. http://hir.harvard.edu/article/?a=13799 (accessed on 14 November 2017).

HUNT, Therese A. 2017. "A Network of One's Own:Young Women and the Creation of Youth-only Transnational Feminist Spaces." Young 25(2): 10723.

JACOBS, Andrew. 2015. "Taking Feminist Battle to China's Streets, and Landing in Jail." Asia Pacific 5 April. https://www.nytimes.com/2015/ 04/06/world/asia/chinese-womens-rights-activists-fall-afoul-ofofficials.html?hp\&action=click\&pgtype=Homepage \&module=first-column-region\&region=top-news\&WT.nav=top-news\&_r=0 (accessed on 8 April 2016).

KERZER, David I. 1983. "Generation as a Sociological Problem." Annual Review of Sociology 9:133.

KO, Dorothy, and Zheng WANG. 2006. "Introduction: Translating Feminisms in China." Gender \& History 18(3): 463-71.

LI, Jun, and Xiaoqin LI. 2017. "Media as a Core Political Resource:The Young Feminist Movements in China." Chinese Journal of Communication 10(1): 54-71. 
LEUNG, Alicia S.M. 2003. "Feminism in Transition: Chinese Culture, Ideology and the Development of the Women's Movement in China." Asia Pacific Journal of Management 20: 359-74.

LEE. 2016. “大兔：我是马克思主义的女权主义者” (Datu: woshi makesizhuyi de nüquanzhuyizhe, Datu: I am a marxian feminist). 26 May. http://thegroundbreaking.com/archives/37355 (accessed on 26 September 2017).

LIU, Wen, Ana HUANG, and Jingchao MA. 2015. "Young Activists, New Movements: Contemporary Chinese Queer Feminism and Transnational Genealogies." Feminism \& Psychology 25(1): 11-7.

MANNHEIM, Karl. 1952. "The Problem of Generations." In Paul Kecskemeti (eds.), Essays on the Sociology of Knowledge: Collected Works. Volume 5. New York: Routledge. 276-322.

MILWERTZ, Cecilia, and Wei BU. 2007. "Non-Governmental Organising for Gender Equality in China - Joining a Global Emancipatory Epistemic Community." The International Journal of Human Rights 11(1-2): 131-49.

MILWERTZ, Cecilia. 2010. "It Is the People Who Serve the Government" Interview with Ai Xiaoming. In Pauline Stoltz, Marina Svensson, Sun Zhongxin, and Qi Wang (eds.), Gender Equality, Citizenship and Human Rights: Controversies and Challenges in China and the Nordic Countries. Abingdon: Routledge. 31-46.

MOHANTY, Chandra Talpade. 2016. "Series Editor's Foreword," In Qi Wang Min Dongchao, and Bo Frenland Sørensen (eds.), Revisiting Gender Inequality: Perspectives from the People's Republic of China. Basingstoke: Palgrave Macmillan. ix.

PILCHER, Jane. 1994. "Mannheim's Sociology of Generations: An Undervalued Legacy." The British Journal of Sociology 45(3): 481-95.

REGER, Jo. 2014. Everywhere and Nowhere: Contemporary Feminism in the United States. New York: Oxford University Press.

ROSEN, Stanley. 2009. "Contemporary Chinese Youth and the State." The Journal of Asian Studies 68(2): 359-69.

SABET, Denise. 2011. "Confucian or Communist, Post-Mao or Postmodern? Exploring the Narrative Identity Resources of Shanghai's Post-80s Generation." Symbolic Interaction 34(4): 536-51.

SCHUMAN, Howard, and Jacqueline SCOTT. 1989. "Generations and Collective Memories." American Sociological Review 54: 395-81.

SCHNITTKER, Jason, Jeremy FREESE, and Brian POWELL. 2003. "Who Are Feminists and What Do They Believe? The Role of Generations." American Sociological Review 68(4): 607-22. http://www.Jstor.org/stable/1519741 (accessed on 21 April 2016).

SHIMEI Keyi 诗美可亦. 2014. “为何中国男人这么反女权? 女性主义为何 在中国遭受的阻力如此之大?" (Weihe Zhongguo nanren zheme fan nüquan? Nüxingzhuyi weihe zai Zhongguo zaoshou de zuli ruci zhida?, Why are Chinese men so anti-feminist? Why does feminism meet such strong resistance in China?), SHIMEI Keyi's blog 13 November 2014. http://blog.sina.com.cn/s/blog_e4c72acb0102vb76.html (accessed on 19 December 2017).

TSUI, Ming, and Lynne RICH. 2002. "The Only Child and Educational Opportunity for Girls in Urban China." Gender \& Society 16(1): 74-92.

VOLODZKO, David. 2015. "Feminism with Chinese Characteristics." The Diplomat 19 October. http://thediplomat.com/2015/10/feminism-withchinese-characteristics/ (accessed on 4 May 2016).

WESOKY, Sharon R. 2017. "(Dis)Continuities in Chinese Feminisms: Navigating Local and Global." WAGIC Women and Gender in China 18 September. https://www.wagic.org/blank-2/2017/08/29/Discontinuities-in-Chi nese-Feminisms-Navigating-Local-and-Global (accessed on 8 December 2017).

WANG, Zheng. 2015. "Detention of the Feminist Five in China." Feminist Studies 41(2): 476-82.
WANG, Zheng 王政. 2017. “密大教授王政谈女权之声遭禁言, 被遮蔽的 社会主义女权历史” (Mida jiaoshou Wang Zheng tan nüquanzhisheng zao jinyan, bei zhebi de shehuizhuyi nüquan lishi, Michigan University Professor Wang Zheng talking about the banning of the voice of women's rights and the obscuring of the history of socialist feminism). China Digital Times 9 March 2017. http://chinadigitaltimes.net/chinese/2017/03/ \%E5\%AF\%86\%E5\%A4\%A7\%E6\%95\%99\%E6\%8E\%88\%E7\%8E\%8B\%E 6\%94\%BF\%E8\%B0\%88\%E5\%A5\%B3\%E6\%9D\%83\%E4\%B9\%8B\%E5\% A3\%B0\%E9\%81\%AD\%E7\%A6\%81\%E8\%A8\%80\%E3\%80\%81\%E8\%A2 \%AB\%E9\% 81\%AE\%E 8\% 94\%BD\%E 7\% 9A\% 84\% E 7\%A\%BE\%E 4\%BC\%9A\%E4\%B8\%BB/ (accessed on 27 March 2017).

WANG, Zheng. 2017. "Feminist Struggles in a Changing China." In Amrita Basu (eds.), Women's Movement in the Global Era: The Power of Local Feminisms. Boulder:Westview Press. 155-81.

WHITTIER, Nancy. 1997. "Political Generations, Micro-Cohorts, and Transformation of Social Movements." American Sociological Review 62(5): 760-78. http://www.Jstor.org/stable/2657359 (accessed on 21 April 2016).

WU, Rongrong. 2015. "How I became a Women's Rights Advocate." China Change 27 April. http://chinachange.org/tag/feminist-activism (accessed on 6 April 2016).

WANG, Qi, Dongchao MIN, and Bo Ærenland SØRENSEN (eds.). 2016. Revisiting Gender Inequality: Perspectives from the People's Republic of China. Basingstoke: Palgrave Macmillan.

WANG, Wendy. 2005. "Son Preference and Educational Opportunities of Children in China" — "I Wish You Were a Boy!" Gender Issues 22(2): 3-30.

WEI, Wei. 2015. "Street, Behavior, Art: Advocating Gender Rights and the Innovation of a Social Movement Repertoire." Chinese Journal of Sociology 1(2): 279-304.

WU, Danyang. 2015. "Youth Feminist Activism in China." Master thesis of Science in Social Studies of Gender, Lund University. http://lup.lub.lu.se/ student-papers/record/7853550 (accessed on 4 April 2016).

YAN, Yunxiang. 2010. "Introduction: Conflicting Images of the Individual and Contested Process of Individualization." In Mette Halskov Hansen, and Rune Svarverud (eds), iChina-The Rise of the Individual in Modern Chinese Society. Copenhagen: NIAS Press. 1-38.

YAN, Yunxiang. 2013. "Parent-driven Divorce and Individualization Among Urban Chinese Youth." International Social Science Journal 64(213-214): 317-30.

YI, Xiang, Barbara RIBBENS, and Caryn N. MORGEN. 2010. "Generational Differences in China: Career Implications." Career Development International 15(6): 601-20.

Yige 一格. 2016. “为什么西方女权更'低调'时, 中国女权运动愈发'激进化 '?" (Weishenme xifang nüquan geng 'didiao' shi, Zhongguo nüquanyundong yufa 'jijinhua?,'Why has the feminist movement in China become increasingly radical while the Western women's rights movement is on ebb?). Sixiang shichang 2 August 2016. http://www.thepaper.cn/newsDetail_forward_1484642 (accessed 19 December 2017).

YUEN, Samson. 2015. "Friend or Foe? The Diminishing Space of China's Civil Society." China Perspectives 2015(3): 51-6.

ZHAO, Feng. 2011. "The Evolution from Generation to Post-XX." Chinese Education \& Society 44(2-3): 76-9.

ZENG, Jinyan. 2017. "Visualizing Truth-telling in Ai Xiaoming's Documentary Activism." Studies in Documentary Film 11(3): 184-99.

ZHANG, Lu. 2009. "Chinese Women Protesting Domestic Violence: The Beijing Conference, International Donor Agencies, and the Making of a Chinese Women's NGO." Meridians: Feminism, Race, Transnationalism 9(2): 66-99. 
ZHANG Lüyuan, XIAO Yujie, and JIANG Yongpen. 2014. “女性主义者：我 们不止独白" (Nüxingzhuyizhe: women buzhi dubai, Feminists: We are not only monologuing). Ziqiang Xinwen 8 March. https://news.ziqiang.studio/ article/16710/ (accessed on 22 August 2017).

ZHAO Sile 赵思乐. 2015. “女权主义者用三十七天建造抗争里程碑” (Nüquanzhuyizhe yong sanshi qi tian jianzao kangzheng lichengbei, Feminists build a milestone of protest for 37 days). China Digital Times 14 April. http://chinadigitaltimes.net/chinese/2015/04/herstory\%E4\%B8\%A8\%E5 \%A5\%B3\%E6\%9D\%83\%E4\%B8\%BB\%E4\%B9\%89\%E8\%80\%85\%E7\%9 4\%A837\%E5\%A4\%A9\%E5\%BB\%BA\%E9\%80\%A0\%E6\%8A\%97\%E4\%B A\%89\%E9\%87\%8C\%E7\%A8\%8B\%E7\%A2\%91/ (accessed on 27 March 2017).

ZHOU Jing 周竟. 2012. "中国十二所师范院校女大学生致信校长要求扩建 女测" (Zhongguo shiersuo shifanyuanxiao nüdaxuesheng zhixin xiaozhang yaoqiu kuojian nüce, Female students from twelve normal universities in China send letters to their rector demanding more female toilets to be build). Xinhuawang 19 November. http://politics.people.com.cn/n/2012/ 1120/c1001-19629417.html (accessed on 25 September 2017).
ZURNDORFER, Harriet. 2016. "Men, Women, Money, and Morality: The Development of China's Sexual Economy." Feminist Economics 22(2): $1-23$.

\section{Interviews}

Interview 1 with S, a Shanghai-based feminist scholar. 19, 26, 27, 28, 29 September 2017.

Interview 2 with W, a Shanghai-based sociologist. 26 September 2017. Interview 3 with X, a Beijing-based feminist activist. 10, 12, 21 October 2017. Personal communication with Li Sipan via WeChat, 30 May and 14 August 2018. 